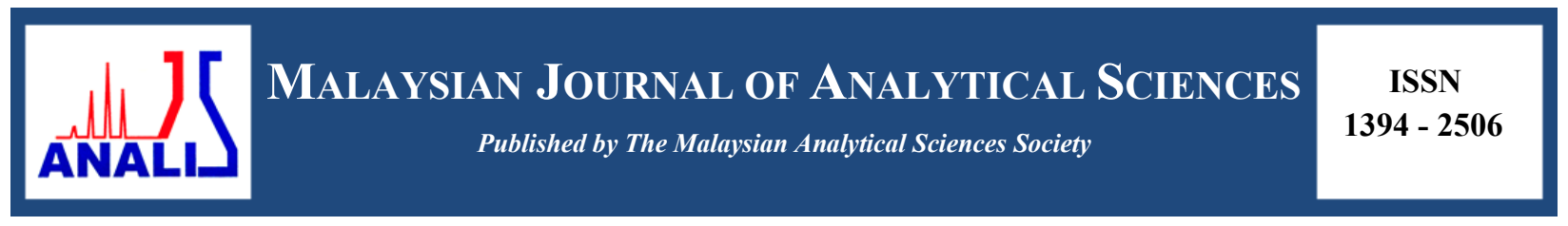

\title{
EFFECTS OF RAIN pH, SOIL ORGANIC MATTER, CATION EXCHANGE CAPACITY AND TOTAL LEAD CONTENT IN SHOOTING RANGE SOIL ON THE CONCENTRATION OF LEAD IN LEACHATE
}

\author{
(Kesan pH Hujan, Jirim Organik Tanah, Kapasiti Tukaran Kation dan Kandungan Plumbum di \\ dalam Tanah Lapang Sasar ke atas Kepekatan Plumbum di dalam Air Larut Lesap) \\ Soon Kong Yong ${ }^{1 *}$, Siti Norazieyana Mohd Zin ${ }^{1}$, Madinah Jaafar Mad Ariff ${ }^{2}$ \\ ${ }^{I}$ Faculty of Applied Sciences, \\ Universiti Teknologi MARA, 40450 Shah Alam, Selangor, Malaysia \\ ${ }^{2}$ Centre for Foundation Studies, \\ Universiti Pertahanan Nasional Malaysia, Kem Sungai Besi, 57000 Kuala Lumpur, Malaysia \\ *Corresponding author: yongsk@salam.uitm.edu.my
}

Received: 17 August 2015; Accepted: 23 May 2016

\begin{abstract}
Leaching of lead $(\mathrm{Pb})$ from the shooting range soil may contaminate water resource if rain $\mathrm{pH}$ decreases and soil has a low cation exchange capacity (CEC). Over exposure of $\mathrm{Pb}$ may cause brain injury and death. In this study, leaching of $\mathrm{Pb}$ from shooting range soil was simulated with column leaching test using artificial rain at $\mathrm{pH} 4$ and 7. Soil physico-chemical parameters (i.e. $\mathrm{pH}$, organic matter $(\mathrm{OM})$, and $\mathrm{CEC})$ were determined, and its' correlation with $\mathrm{Pb}$ concentrations in soil $(\mathrm{Soil} \mathrm{Pb})$ and leachate (Leachate $\mathrm{Pb}$ ) were studied using Pearson's correlation. Compare to control soil, shooting range soil has higher contents of $\mathrm{Pb}$ $(12,163-17,278 \mathrm{mg} / \mathrm{kg}$, dry weight basis) and sand $(64-68 \%)$. The CEC value of shooting range soil $(193 \mathrm{cmol} / \mathrm{kg}$ at $\mathrm{pH} 7)$ is lower than those in control soil $(85-140 \mathrm{cmol} / \mathrm{kg}$ at $\mathrm{pH} 7)$, possibly due to low contents of clay and OM. There is positive correlation between Soil $\mathrm{Pb}$ and Leachate $\mathrm{Pb}$ variable pair $(r=0.94 ; p=0.06)$; while Soil $\mathrm{OM}$ and Leachate $\mathrm{Pb}$ variable pair has a negative correlation $(r=-0.94 ; p=0.06)$. In conclusion, the combination of high soil $\mathrm{Pb}$ content, low $\mathrm{CEC}$, and low rain $\mathrm{pH}$ increases leaching of $\mathrm{Pb}$ from shooting range soil.
\end{abstract}

Keywords: lead shots, heavy metal, groundwater, acid rain, sorption

\section{Abstrak}

Larut lesap $\mathrm{Pb}$ daripada tanah lapang sasar boleh mencemarkan sumber air jika nilai $\mathrm{pH}$ hujan menurun dan tanah mempunyai keupayaan pertukaran kation (CEC) yang rendah. Pendedahan $\mathrm{Pb}$ yang keterlaluan boleh menyebabkan kecederaan otak dan kematian. Dalam kajian ini, larut lesap $\mathrm{Pb}$ dari tanah lapang sasar telah disimulasikan dengan ujian larut lesap turus menggunakan air hujan tiruan pada $\mathrm{pH} 4$ dan 7. Parameter tanah (iaitu, $\mathrm{pH}$, jirim organik (OM), dan CEC) telah ditentukan, dan dikaji korelasinya dengan kepekatan $\mathrm{Pb}$ di dalam tanah dan larut resap dengan menggunakan korelasi Pearson. Berbanding dengan tanah kawalan, kandungan $\mathrm{Pb}(12163-17278 \mathrm{mg} / \mathrm{kg}$, secara berat kering) dan pasir (64 - $68 \%)$ pada tanah lapang sasar adalah lebih tinggi. Nilai CEC tanah lapang sasar $(193 \mathrm{cmol} / \mathrm{kg}$ pada $\mathrm{pH} 7)$ adalah lebih rendah daripada tanah kawalan $(85-$ $140 \mathrm{cmol} / \mathrm{kg}$ pada $\mathrm{pH} \mathrm{7),} \mathrm{mungkin} \mathrm{disebabkan} \mathrm{oleh} \mathrm{kandungan} \mathrm{rendah} \mathrm{tanah} \mathrm{liat} \mathrm{dan} \mathrm{jirim} \mathrm{organik.} \mathrm{Terdapat} \mathrm{hubungan} \mathrm{yang}$ positif antara pasangan pemboleh ubah $\mathrm{Pb}$ tanah dan $\mathrm{Pb}$ larut lesap $(r=0.94 ; p=0.06)$; manakala pasangan pemboleh ubah jirim organik tanah dan $\mathrm{Pb}$ larut lesap mempunyai korelasi negatif $(r=-0,94 ; p=0.06)$. Kesimpulannya, gabungan faktor-faktor seperti kandungan $\mathrm{Pb}$ yang tinggi di dalam tanah, nilai $\mathrm{CEC}$ tanah yang rendah dan nilai $\mathrm{pH}$ hujan yang rendah boleh meningkatkan risiko larut lesap $\mathrm{Pb}$ dari tanah lapang sasar.

Kata kunci: peluru plumbum, logam berat, air bawah tanah, hujan berasid, jerapan 


\section{Yong et al: EFFECTS OF RAIN pH, SOIL ORGANIC MATTER, CATION EXCHANGE CAPACITY AND TOTAL LEAD CONTENT IN SHOOTING RANGE SOIL ON THE CONCENTRATION OF LEAD IN LEACHATE}

\section{Introduction}

Soils are reservoirs for many harmful heavy metal pollutants, such as copper, lead, cadmium, aluminium, and etc. These metals are released by anthropogenic activities such as mining, smelting, traffic emission and firearm shooting. Bullet contains lead $(90-99 \%)$, antimony $(1-10.5 \%)$, and copper $(0.1 \%)$ may be a point source for lead contamination in the shooting range [1]. Total lead concentration in shooting range soils may be as high as $54,000 \mathrm{mg} / \mathrm{kg}$ [2]. Lead in bullet is subjected to weathering and may lead to accumulation in soil [3]. Metallic lead will be converted to hydrocerussite $\left(\mathrm{Pb}_{3}\left(\mathrm{CO}_{3}\right)_{2}(\mathrm{OH})_{2}\right)$, cerussite $\left(\mathrm{PbCO}_{3}\right)$, and massicot $(\mathrm{PbO})$ within one week [2].

Lead is toxic to human health especially for children, as it attacks the brain and central nervous system. High level exposure of lead may cause coma, convulsions and even death. Ecological risks of lead at shooting range may also be significant. High level of lead may affect local and migratory, aquatic and terrestrial biota. The risk of lead contamination in groundwater system is higher with high content of lead in shooting range soil [4], and close proximity of groundwater table to the surface of shooting range soil. As groundwater is used as daily drinking water, these contaminations may affect human health.

To the best of our knowledge, there is no study on the risk of lead contamination in groundwater from shooting range soil in Malaysia. Lead contamination in groundwater may depends on the several soil physico-chemical parameters (i.e. soil $\mathrm{pH}, \mathrm{CEC}$ and $\mathrm{OM}$ ), and the $\mathrm{pH}$ of rain water. The objectives of this study to determine the soil physico-chemical parameters and the soil lead content at the Kem Sungai Besi shooting range, and to simulate the leaching process using artificial rain at various $\mathrm{pH}$ values. A correlation study was conducted to determine the risk factors for lead contamination in the groundwater.

\section{Soil collection and preparation}

\section{Materials and Methods}

Soil samples were collected using the coring technique at a sampling site ( $3^{\circ} 3^{\prime} 0^{\prime \prime}$ North, $101^{\circ} 42^{\prime} 0^{\prime \prime}$ East) located at Kem Sungai Besi, Kuala Lumpur, Malaysia. Baseline soil was taken at the boundary of the shooting range, and is free of the bullets and lead shots. Target 4, 6 and 8 located at the center of the berm were chosen as sampling points. Little vegetation was observed on the target soils (Figure 1a). Three soils replicates were collected at the top, middle and bottom of each targets, and were homogenized to form composite sample (Figure 2).

The soil samples were air dried for 6 days before being sieved to $2 \mathrm{~mm}$. After sieving, the fragment of bullets was hand-picked from the soil sample. The fragments were visibly corroded and have reduced in size, indicating the weathering process of lead shots in the soil (Figure 1b). The soil samples were kept in air-tight plastic container to avoid contact with moisture.

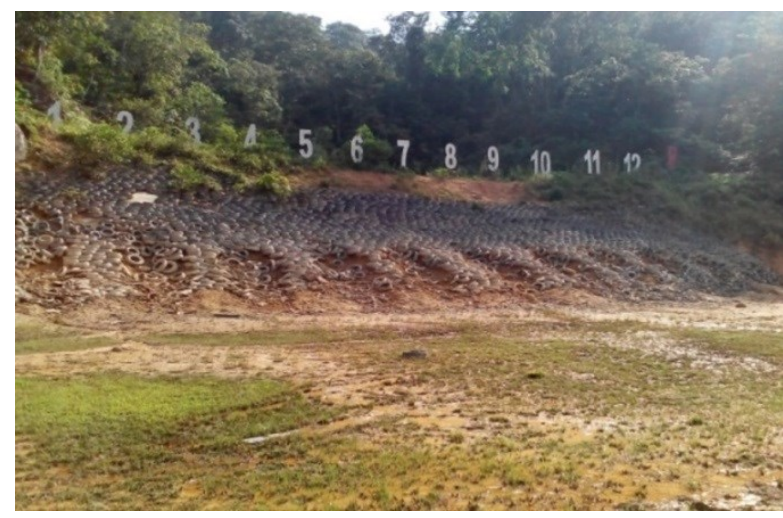

(a)

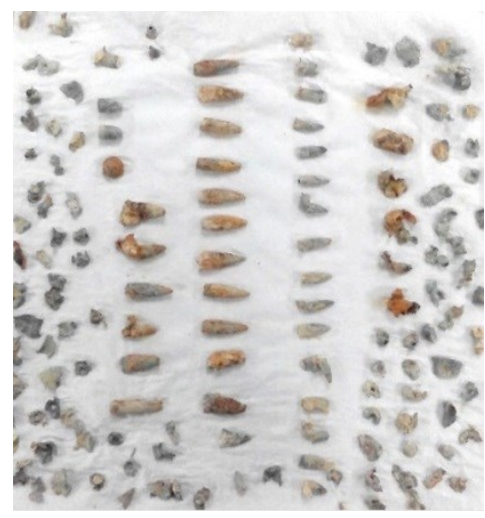

(b)

Figure 1. Shooting range (a) and bullet fragments (b) at Kem Sungai Besi, Kuala Lumpur 

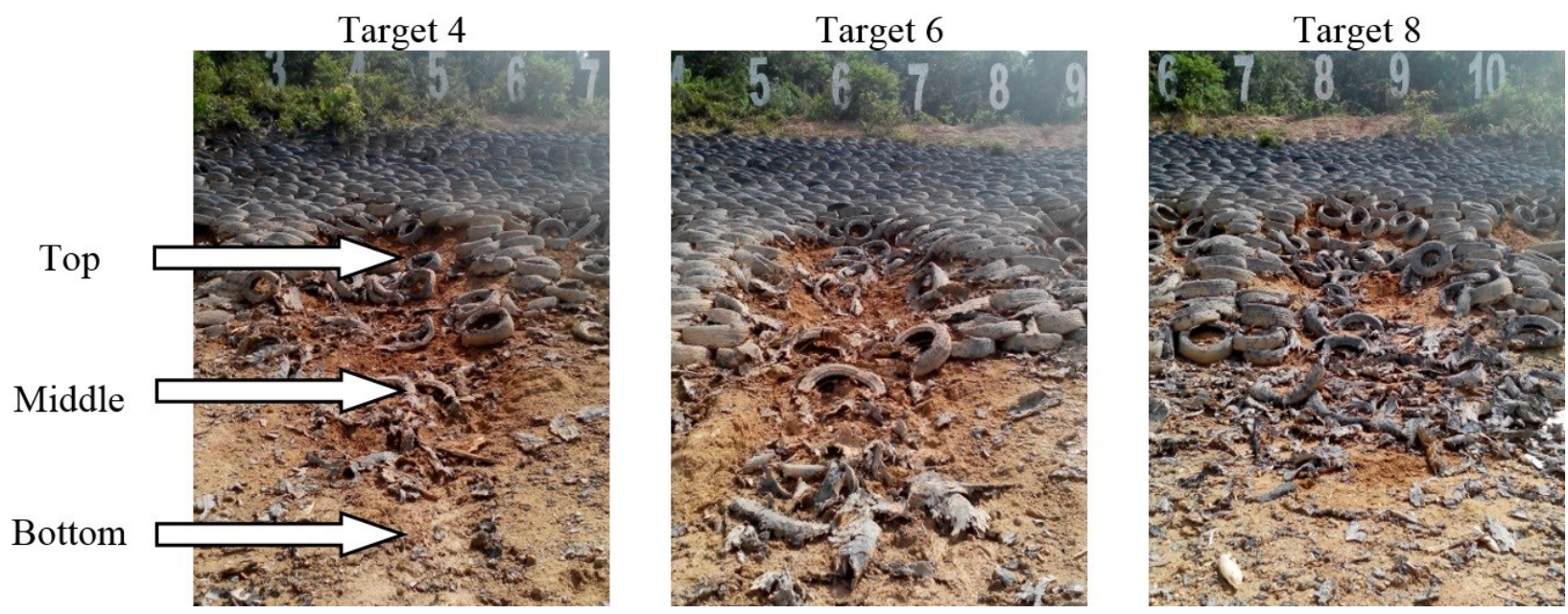

Figure 2. The location of soil sampling points at target 4,6 , and 8

\section{Soil pH}

Soil $\mathrm{pH}$ was measured on a soil-deionized water suspension $(1: 1 \mathrm{w} / \mathrm{v}$ ratio) using a calibrated $\mathrm{pH}$ meter. Twenty grams of soil samples from shooting target were suspended in $20 \mathrm{~mL}$ deionized water in a $100 \mathrm{~mL}$ beaker. The suspension was mixed using a glass rod and allowed to stand for 30 min with interval stirring at 10 min and again after $1 \mathrm{~h}$ to ensure complete homogeneity. The $\mathrm{pH}$ reading was taken after immersing the $\mathrm{pH}$ meter into the suspension (at about $3 \mathrm{~cm}$ depth) for $30 \mathrm{sec}$ at $25^{\circ} \mathrm{C}$.

\section{Soil particle distribution}

Soil particles distribution was determined through the hydrometer method. A dispersing solution was prepared by dissolving $40 \mathrm{~g}$ sodium hexametaphosphate $\left[\left(\mathrm{NaPO}_{3}\right)_{6}\right]$ and $10 \mathrm{~g}$ of sodium carbonate $\left(\mathrm{Na}_{2} \mathrm{CO}_{3}\right)$ in $1 \mathrm{~L}$ of volume with deionized water. Sixty millilitres of dispersing solution was poured into a $600 \mathrm{~mL}$ beaker containing $40 \mathrm{~g}$ of soil sample. The beaker was covered with watch glass and left overnight. The content was stirred for 3 min and then transferred quantitatively into a $1 \mathrm{~L}$ calibrated cylinder and was brought to volume with deionized water. To determine the distribution of a mixture of silt and clay, the suspension was mixed in the hydrometer jar. After the paddle is withdrawn, the hydrometer was inserted into the jar and the reading $\left(R_{s c}\right)$ was taken after $40 \mathrm{sec}$. For clay particle distribution determination, the solution was left undisturbed for $4 \mathrm{~h}$ before the reading $\left(R_{c}\right)$ was recorded. For the determination of silt in the soil, the suspension was sieved into $50 \mu \mathrm{m}$ sieve. The sieved soil was washed with water until the sieve is clear. The sand was quantitatively transferred to crucible of known weight. The crucible then was dried in the oven at $105{ }^{\circ} \mathrm{C}$ overnight. The crucible was cooled in desiccator and weighed.

\section{Soil organic matter}

The organic matter (OM) in the soil was estimated as soil organic carbon (SOC), using the loss-on-ignition method (LOI). Crucibles were dried at $105{ }^{\circ} \mathrm{C}$ for at least $1 \mathrm{~h}$ and cooled in dessicator for $30 \mathrm{~min}$. About $5.0 \mathrm{~g}$ of soil was transferred into the crucible; oven dried overnight at $105^{\circ} \mathrm{C}$, cooled in dessicator and reweighed using an analytical balance. The crucible was placed into a furnace at $450^{\circ} \mathrm{C}$ for $4 \mathrm{~h}$, and reweigh after proper cooling. The percentage of LOI and SOC were determined using Eq. 1 and Eq. 2, respectively.

$$
\mathrm{LOI}=\frac{\left(W_{3}-W_{1}\right)-\left(W_{2}-W_{1}\right)}{\left(W_{2}-W_{1}\right)} \times 100
$$




$$
\mathrm{SOC}=\frac{L O I}{1.72}
$$

where $W_{1}$ is the weight of empty crucible; $W_{2}$ is the weight of crucible and soil samples before ignition; and $W_{3}$ is the weight of crucible and soil samples after ignition.

\section{Cation exchange capacity}

The CEC values were determined with the sodium acetate method. Four grams of soil sample was mixed with 30 $\mathrm{mL}$ of $1.0 \mathrm{~N}$ sodium acetate $(\mathrm{NaOAc})$ solution in a $50 \mathrm{~mL}$ centrifuge tube for 5 min using a mechanical shaker. Then the content was centrifuged and the supernatant was decanted. The step was repeated thrice using $\mathrm{NaOAc}$ solution. Thirty three millilitres of $99 \%$ isopropyl alcohol was added to the centrifuge tube. Then, the tube was shaken in mechanical shaker for $5 \mathrm{~min}$ and centrifuged to decant the liquid. This step was repeated for twice. Next, $33 \mathrm{~mL}$ of ammonium acetate $\left(\mathrm{NH}_{4} \mathrm{OAc}\right)$ solution was added into the tube. Then, the tube is shaken for $5 \mathrm{~min}$. The liquid was centrifuged and the supernatant was decanted into a $100 \mathrm{~mL}$ volumetric flask. The procedure was repeated twice. The combined washing was diluted to $100 \mathrm{~mL}$ with $\mathrm{NH}_{4} \mathrm{OAc}$ solution and the solution was analysed using Inductively Couple Plasma- Optical Emission Spectrometry (ICP-OES) for sodium concentration.

\section{Acid digestion of soil sample}

About $0.5 \mathrm{~g}$ of soil sample was digested in $100 \mathrm{~mL}$ beaker using aqua regia solution. The content of the beaker was heated at $100{ }^{\circ} \mathrm{C}$ until the volume of acid is decreased to about $5 \mathrm{~mL}$ without precipitation. Digested solution was cooled, filtered and diluted to $50 \mathrm{~mL}$ in a volumetric flask. The metal composition of the digested solution was analysed using ICP-OES.

\section{Soil column leaching test}

A glass column with $13 \mathrm{~cm}$ height and $4 \mathrm{~cm}$ diameter was used in the column leaching test. This column was packed to about $10 \mathrm{~cm}$ height, using composite of soil samples from three targets at the shooting range. The soil composite was transferred to the glass column in small portions to obtain uniform packing. The soil column was pre-wetted with artificial rain $\left(0.01 \mathrm{M} \mathrm{CaCl}_{2}, \mathrm{pH} 7\right)$ from the top to bottom in order to displace the air in the soil pores. The soil then was allowed to equilibrate and the excess water was drained off by gravity. Then, $200 \mathrm{~mL}$ artificial rainwater was applied to the soil column. To obtain homogenous distribution the solution, the artificial rainwater was applied evenly over the surface of the soil column. The surface of the soil column was covered with a gauze cloth to ensure even distribution of the artificial rain, and to avoid the disturbance of the soil surface by the rain drops. With the aid of peristaltic pump, a total of $600 \mathrm{~mL}$ artificial rain was added drop-wise on to the top of the soil column. Soil leaching test was repeated using $0.01 \mathrm{M} \mathrm{CaCl}_{2}$ at $\mathrm{pH} 4$. Leachates were collected in three successive fractions, and were analysed with ICP-OES.

\section{Correlation studies}

Correlation of $\mathrm{Pb}$ concentrations in leachate fractions (i.e. Leachate $\mathrm{Pb}$ ) and soil physico-chemical parameters (i.e., Soil Pb, Soil pH, Soil OM, CEC) were analysed with Pearson correlation using SPSS version 13.

\section{Physico-chemical properties of shooting range soil}

\section{Results and Discussion}

The physico-chemical properties (i.e., $\mathrm{pH}, \mathrm{OM}, \mathrm{CEC}$ ), soil composition and lead concentration in shooting range soil are shown in Table 1 . The $\mathrm{pH}$ of the soil is slightly acidic (i.e. 5.55 to 6.34). The acidity may be due to acid deposition from the atmosphere in Kuala Lumpur [5]. Baseline soil has a similar $\mathrm{pH}$ value (5.54) with those at the targets. The percentage of the silt, sand, and clay in the soil are $9 \%, 66 \%$ and $27 \%$, respectively. The soil texture is of sandy clay loam according to United States Department of Agriculture (USDA) soil textural diagram. The OM content for baseline soil is $5.40 \%$, which is higher than those at the targets (i.e. 1.32 to $1.55 \%$ ). Vegetation on top of the baseline soil may have contributed to higher plant biomass and OM contents. Moreover, baseline soil has higher CEC value compared to those at three targets, possibly due to the higher OM contents in baseline soil [6]. However, the CEC value of all soil samples decreased with decreasing $\mathrm{pH}$ value. A large CEC value of the soil samples is crucial for holding large amounts of lead cations. However, a combination of low rain $\mathrm{pH}$, low clay 
content and OM content in soil may increase the risk for dissolution and mobilization of lead from shooting range soils into groundwater [7].

Table 1. Physico-chemical properties, particle size distribution and concentrations of $\mathrm{Pb}, \mathrm{Al}, \mathrm{Fe}, \mathrm{Ca}$, and $\mathrm{K}$ in shooting range soil at target 4, 6 and 8 .

\begin{tabular}{lcccc}
\hline \multirow{2}{*}{ Variable } & \multicolumn{4}{c}{ Field soil } \\
\cline { 2 - 5 } & Baseline & Target 4 & Target 6 & Target 8 \\
\hline $\mathrm{pH}$ & 5.54 & 5.85 & 6.34 & 5.55 \\
$\mathrm{OM}(\% \mathrm{LOI})$ & 5.40 & 1.55 & 1.37 & 1.32 \\
\% Clay & 32 & 23 & 26 & 25 \\
\% Silt & 13 & 9 & 10 & 8 \\
\% Sand & 55 & 68 & 64 & 67 \\
$\mathrm{CEC}-\mathrm{pH} 7,(\mathrm{cmol} / \mathrm{kg})$ & 193.85 & 140.21 & 85.51 & 85.25 \\
$\mathrm{CEC}-\mathrm{pH} 4,(\mathrm{cmol} / \mathrm{kg})$ & 112.15 & 62.70 & 54.76 & 57.00 \\
$\mathrm{~Pb},(\mathrm{mg} / \mathrm{kg}, \mathrm{dw})$ & 4.4 & 17278 & 14126 & 12163 \\
$\mathrm{Al},(\mathrm{mg} / \mathrm{kg}, \mathrm{dw})$ & 380 & 372 & 347 & 333 \\
$\mathrm{Fe},(\mathrm{mg} / \mathrm{kg}, \mathrm{dw})$ & 178 & 152 & 172 & 154 \\
$\mathrm{Ca},(\mathrm{mg} / \mathrm{kg}, \mathrm{dw})$ & 132 & 106 & 112 & 16 \\
$\mathrm{~K},(\mathrm{mg} / \mathrm{kg}, \mathrm{dw})$ & 27 & 13 & 11 & 13 \\
\hline
\end{tabular}

The concentration of the lead and other metal in shooting range soil is shown in Table 1 . The average total lead contents at the targets are $14522 \pm 2580 \mathrm{mg} / \mathrm{kg}$, significantly higher than those at the baseline $(4.4 \mathrm{mg} / \mathrm{kg})$. The concentration of lead in soil is also the highest compare to other metals, indicating the excessive enrichment of lead in the shooting range soil. The average lead concentration in target soils is 36 times higher than the limits set by United States Environment Protection Agency (USEPA) [8].

\section{Soil column leaching test}

Figure 3 shows the average lead concentration in leachate from baseline and target soils, eluted with artificial rain water at $\mathrm{pH} 7$ and 4 . Overall, the lead concentration in leachate is higher than the safe limit $(0.10 \mathrm{mg} / \mathrm{L})$ set by the Ministry of Natural Resources and Environment [9]. The lead concentration in leachate decreased with successive fractions for all soil samples. The highest lead concentration was recorded in the leachate of target soil at $\mathrm{pH} 4$. Lead concentrations of leachates from target soil are higher than those of baselines soil at $\mathrm{pH} 4$ and 7 . High lead content of target soils increases the amount of soluble lead ions in leachate. The concentration of lead is further increased by acidic rain water, possible due to: (1) decrease of CEC of soil, and (2) increased solubility of lead in the soil [10]. This leaching behaviour shows that the risk of leaching of lead is significantly increased in the event of acid rain.

In Table 2, the Pearson's correlation coefficient $(r)$ value for lead concentration in soil $(\mathrm{Soil} \mathrm{Pb})$ and leachate (Leachate $\mathrm{Pb}$ ) variables pair is 0.938 , which means the concentration of lead in leachate increases with increasing of lead concentration in soil. The CEC and Soil OM variables pair has positive correlation $(r=0.891)$. The surface of OM may contain negatively-charged polar functional groups (i.e. carboxylate or phenolic groups) that can attract cations and help increase the CEC value of the soil [11]. The negative $r$ values for Leachate $\mathrm{Pb}$ variable with both $\mathrm{CEC}$ and Soil OM variables show negative correlations. Decreasing OM and CEC values may depletes the capacity of the soil for retaining $\mathrm{Pb}$ ion, thereby, increasing the $\mathrm{Pb}$ concentration in leachate. Leachate $\mathrm{Pb}$ variable is positively-correlated with Soil $\mathrm{Pb}$ variable $(r=0.94 ; p=0.06)$; but is negatively-correlated with the Soil $\mathrm{OM}$ variable $(r=-0.94 ; p=0.06)$. This indicate that $\mathrm{Pb}$ in shooting range soil is the source for $\mathrm{Pb}$ ions in the leachate, 


\section{Yong et al: EFFECTS OF RAIN pH, SOIL ORGANIC MATTER, CATION EXCHANGE CAPACITY AND TOTAL LEAD CONTENT IN SHOOTING RANGE SOIL ON THE CONCENTRATION OF LEAD IN LEACHATE}

and increasing $\mathrm{Pb}$ in soil causes higher concentration of $\mathrm{Pb}$ in the leachate. High soil $\mathrm{OM}$ content may reduce leaching of $\mathrm{Pb}$ through sorption with polar functional groups in the $\mathrm{OM}[12,13]$.

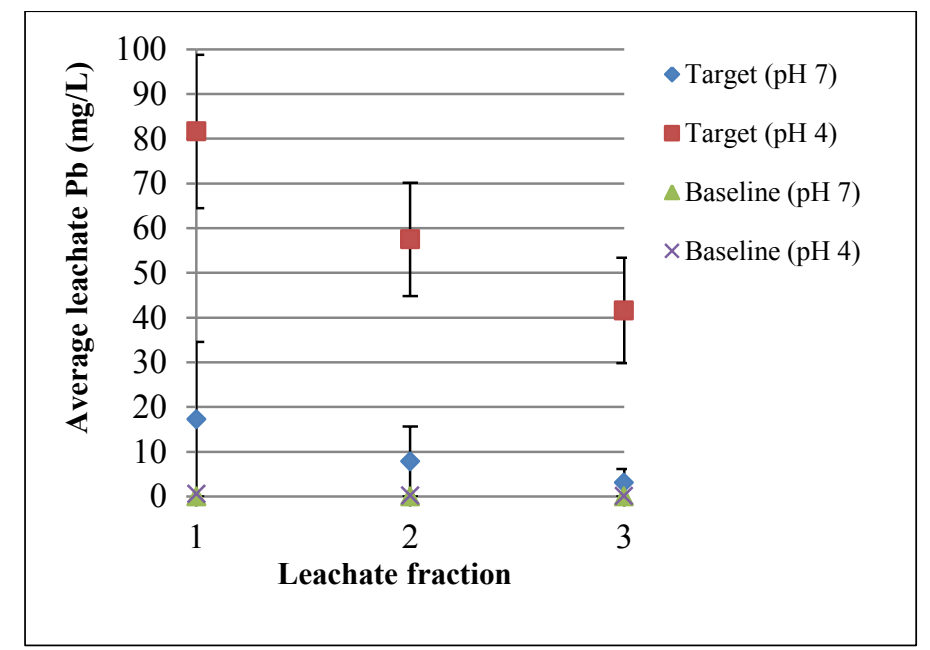

Figure 3. Concentration of lead in leachate $(\mathrm{mg} / \mathrm{L})$ from baseline and target soil at $\mathrm{pH} 4$ and 7 as a function of leachate fraction

Table 2. Pearson's correlation coeffeicient $(r)$ and significance level $(p)$ for variables pairs

\begin{tabular}{llccccc}
\hline Variable & & Soil Pb & Soil pH & Soil OM & CEC & Leachate Pb \\
\hline \multirow{2}{*}{ Soil $\mathrm{Pb}$} & $r$ & 1 & 0.550 & -0.946 & -0.705 & 0.938 \\
& $p$ (2-tailed) & & 0.450 & 0.054 & 0.295 & 0.062 \\
& $r$ & 0.550 & 1 & -0.500 & -0.485 & 0.250 \\
Soil $\mathrm{pH}$ & $p$ (2-tailed) & 0.450 & & 0.500 & 0.515 & 0.750 \\
& $r$ & -0.946 & -0.500 & 1 & 0.891 & -0.939 \\
Soil OM & $p$ (2-tailed) & 0.054 & 0.500 & & 0.109 & 0.061 \\
& $r$ & -0.705 & -0.485 & 0.891 & 1 & -0.721 \\
CEC & $p$ (2-tailed) & 0.295 & 0.515 & 0.109 & & 0.279 \\
& $r$ & 0.938 & 0.250 & -0.939 & -0.721 & 1 \\
Leachate $\mathrm{Pb}$ & $p$ (2-tailed) & 0.062 & 0.750 & 0.061 & 0.279 & \\
& & & & & &
\end{tabular}

\section{Conclusion}

The risk of leaching of the lead from the shooting range soil at Kem Sungai Besi is a concern due to (1) high concentration of lead in shooting range soil, (2) high percentage of sand in the shooting range soil, (3) lower rain $\mathrm{pH}$ value at Kuala Lumpur and Selangor [14], and (4) low CEC value from low soil OM content. On normal radiation practice, soil liming is employed to increase soil $\mathrm{pH}$, and converts lead ions to insoluble hydroxide complexes. However, increasing soil $\mathrm{pH}$ may also increase the soluble fraction of the soil OM (i.e. DOM). Lead concentration in leachate may be increased due to an increased formation of soluble lead-DOM complex. In situ remediation method can be used to reduce the possibility of leaching of lead to groundwater. An immediate and economic 
solution to this problem is by artificially increasing recalcitrant soil OM (i.e., activated carbon, biochar) to increase immobilization of soil $\mathrm{Pb}$. Further study on the bore waters and air borne particles at the shooting range is warranted to understand the actual migration and impact of soil $\mathrm{Pb}$ to water resources.

\section{Acknowledgement}

The authors would like to thank the Ministry of Higher Education, Malaysia for financing this project under the Research Acculturation Collaborative Effort (RACE) Grant [600-RMI RACE 16/6/2 (2/2014)], and the Universiti Teknologi MARA for the financial assistance for participation in the SKAM28 conference.

\section{References}

1. Clausen, J., Bostick, B. and Korte, N. (2011). Migration of lead in surface water, pore water, and groundwater with a focus on firing ranges. Critical Reviews in Environmental Science and Technology, 41(15): 1397 - 1448.

2. Hardison Jr, D. W., Ma, L. Q., Luongo, T. and Harris, W. G. (2004). Lead contamination in shooting range soils from abrasion of lead bullets and subsequent weathering. Science of the Total Environment, 328(1-3): 175 $-183$.

3. Cao, X., Ma, L. Q., Chen, M., Hardison, D. W. and Harris, W. G. (2003). Lead transformation and distribution in the soils of shooting ranges in Florida, USA. Science of the Total Environment, 307(1): $179-189$.

4. Sorvari, J., Antikainen, R. and Pyy, O. (2006). Environmental contamination at Finnish shooting ranges the scope of the problem and management options. Science of the Total Environment, 366(1): $21-31$.

5. Ayers, G., Peng, L. C., Gillett, R. and Fook, L. S. (2002). Rainwater composition and acidity at five sites in Malaysia, in 1996. Water, Air, and Soil Pollution, 133(1-4): $15-30$.

6. Asadu, C. L. A., Diels, J. and Vanlauwe, B. (1997). A comparison of the contributions of clay, silt, and organic matter to the effective CEC of soils of Subsaharian Africa. Soil Science, 162(11): 785 - 794.

7. Darling, C. T. R. and Thomas, V. G. (2003). The distribution of outdoor shooting ranges in Ontario and the potential for lead pollution of soil and water. Science of the Total Environment, 313(1-3): 235 - 243.

8. USEPA, (2002). Supplemental guidance for developing soil screening levels for superfund sites. Office of Solid Waste and Emergency Response, USEPA: Washington, D.C.

9. Department of Environment (2009). Environmental quality (control of pollution from solid waste transfer station and landfill) regulations. $P U(A) 433$.

10. Sauvé, S., McBride, M. and Hendershot, W. (1998). Soil solution speciation of lead(II): Effects of organic matter and pH. Soil Science Society of America Journal, 62(3): 618 - 621.

11. Liang, B., Lehmann, J., Solomon, D., Kinyangi, J., Grossman, J., O'neill, B., Skjemstad, J., Thies, J., Luizao, F. and Petersen, J. (2006). Black carbon increases cation exchange capacity in soils. Soil Science Society of America Journal, 70(5): $1719-1730$.

12. Yong, S. K., Bolan, N., Lombi, E. and Skinner, W. (2015). Enhanced $\mathrm{Zn}(\mathrm{II})$ and $\mathrm{Pb}(\mathrm{II})$ removal from wastewater using thiolated chitosan beads (ETB). Malaysian Journal of Analytical Sciences, 19(3): 586 - 594.

13. Liew, H. H., Tay, C. C., Yong, S. K., Surif, S. and Abdul Talib, S. (2010). Biosorption characteristics of lead $[\mathrm{Pb}(\mathrm{II})]$ by Pleurotus ostreatus biomass. Proceedings of International Conference on Science and Social Research (CSSR). 2010. Kuala Lumpur.

14. Makmom Abdullah, A., Armi Abu Samah, M. and Yee Jun, T. (2012). An overview of the air pollution trend in Klang Valley, Malaysia. Open Environmental Sciences, 6(1): 13 - 19. 